\title{
URZĄD NAUCZYCIELSKI PAPIEŻA W ŚWIETLE I i II SOBORU WATYKAŃSKIEGO
}

Objawy kryzysu, jakie wystąpiły na niektórych odcinkach życia kościelnego po II Soborze Watykańskim, dają się również zaobserwować - i to może w sposób szczególniejszy - w poglądach na naturę i funkcjonowanie papieskiego Urzędu Nauczycielskiego. Jak wiadomo Encyklika Humanae vitae z dn. 25. VII. 1968 r., dotycząca zasad moralnych w dziedzinie przekazywania ludzkiego życia, a będąca wyrazem nauczania zwyczajnego biskupa rzymskiego, spotkała się z dość licznymi głosami krytyki niektórych środowisk czy poszczególnych wiernych $\mathbf{1}$. Ostatnio znowu H. Küng, ,reinterpretując” dogmat eklezjologiczny I Soboru Watykańskiego, zakwestionował nieomylność uroczystego nauczania papieża ex cathedra ${ }^{2}$. Wobec powyższego, wydaje się wskazane naszkicowanie w głównych zarysach, i to w oparciu o autorytatywne wypowiedzi Vaticanum I i II, katolickiej nauki o papieskim Urzędzie Nauczycielskim. W tym celu należy jednak najpierw prześledzić wzajemne związki istnie-

1 AAS, 60 (1968) 481-503. - Por. L. M. Weber, Exkurs über „Humanae vitae”, w: LThK. Das zweite vatikanische Konzil, 3 (1968) 607-609. - J. Różycki, Teologiczna pewność norm etycznych $w$ encyklice „Humanae vitae", "Analecta Cracoviensia", 1 (1969) 231-257. - T. Slipko, Postulaty stawiane teologii moralnej przez encyklike „Humanae vitae”, tamże, 263-273. - L. Simeone, Difesa di un Papa e di una enciclica, Firenze, 1970.

2 Unfehtbar? Eine Anfrage, Einsiedeln-Zurich, 1970. - Por. na ten temat dyskusję pomiędzy K. Rahnerem i H. Küngiem na łamach: „Stimmen der Zeit”, 12 (1970) 361-377 (Kritik an Hans Küng); 1 (1971) 43-64 (Im Interesse der Sache); 2 (1971) 73-81 (Disput um das kirchliche Lehramt); 3 (1971) 145-160 (Replik) a także dlugłos pomiędzy M. Löhrerem oraz H. Küngiem w: „Diakonia. Der Seelsorger” 1 (1971) 60-69. Nadto: G. Dejaifve, Un débat sur l'infaillibilité. La discussion entre $K$. Rahner et $H$. Küng, „Nouvelle revue théologique”, 93 (1971) 583-601. 
jące pomiędzy Objawieniem i Kościołem, a zwłaszcza jego Magisterium ${ }^{3}$. Dopiero bowiem na tym tle będzie można lepiej ustawić całą złożoną problematykę uroczystego i zwyczajnego nauczania papieży.

\section{OBJAWIENIE A KOSCIÓE}

Objawiony depozyt wiary, zawarty w Piśmie św. i Tradycji, według Dei Verbum - Konstytucji dogmatycznej o Objawieniu Bożym II Soboru Watykańskiego ${ }^{1}$ - został powierzony Kościołowi, tzn. całemu Ludowi Bożemu, katolikom świeckim i ich pasterzom. Lud Boży powinien, żyjąc nim, trwać jednomyślnie w zachowywaniu, praktykowaniu i wyznawaniu przekazywanej sobie wiary ${ }^{5}$. Stwierdzenie to, nie będące samo w sobie żadną rewelacją doktrynalną, stanowi jednak pewien postęp w stosunku do wcześniejszych wypowiedzi Kościoła na ten temat. Dotychczasowe bowiem oficjalne enuncjacje dotyczyły tylko związków istniejących pomiędzy Objawieniem i samym Magisterium, a nie Kościołem jako takim, tzn. całością Ludu Bożego ${ }^{6}$.

Inaczej wygląda kwestia autentycznej i nieomylnej interpretacji Objawienia. Przysługuje ona wyłącznie ,,żywemu Urzędowi Nauczycielskiemu Kościoła - a więc nie wiernym, czy nawet teologom - który autorytatywnie działa w imieniu Jezusa Chrystusa" " . Ujmując najogólniej rolę Magisterium względem Objawienia należy stwierdzić, że ,nie jest ono ponad Słowem Bożym, lecz jemu służy, nauczając tylko tego, co zostało przekazane" 8. Innymi słowy, Urząd Naczycielski Kościoła nie jest „panem”, lecz „sługą” w odniesieniu do Słowa Bożego. Naucza jedynie tego, co zostało mu powierzone. Nie można go zatem uważać - jak to

3 Bardzo dobre, syntetyczne opracowanie tej problematyki znajduje się w: R. Latourelle, Théologie de la Révélation, Bruges-Paris, ${ }^{21966,267-382 ~(N o t i o n ~ d e ~}$ révélation et magistère de l'Eglise); - J. Feiner, Offenbarung und Kirche-Kirche und Offenbarung, w: Mysterium Salutis, Bd 1: Die Grundlagen heilsgeschichtlicher Dogmatik, Benzinger Verlag, 1965, 497-544; - U. Betti, La rivelazione divina nella Chiesa, Città Nuova, 1970. - Por. także: G. Dejaïfve, Révélation et Eglise, „Nouvelle revue théologique", 85 (1963) 563-576. - B. Sesboüé, Autorité du Magistère et vie de foi ecclésiale, tamże, 93 (1971) 337-362.

${ }_{4}^{4}$ Cytaty polskie w artykule są podawane za: Sobór Watykański II. Konstytucje - Dekrety - Deklaracje. Tekst lacińsko-polski, Poznań, 1968, 536-561 (=KO). - Por. Idee przewodnie soborowej Konstytucji o Objawieniu Bożym, Kraków, 1968.

5 KO, 10. - Por. M. Löhrer, Träger der Vermittlung, w: Misterium Salutis, Bd 1: Die Grundlagen der heilsgeschichtlicher Dogmatik, 545-547 (Die Funktion der Kirche als ganzer); 547-555 (Das christliche Volk und die Offenbarungsvermittlung).

6 Latourelle, Théologie de la Révélation, 366-367.

7 KO, 10. - Por. Litt. encycl. „Humani generis”, 12. Aug. 1950: „Quod quidem depositum nec singulis christifidelibus nec ipsis theologis divinus Redemptor concredidit authentice interpretandum, sed soli Ecclesiae Magisterio", DS (2314) 3886. Löhrer, Träger der Vermittlung, 555-586 (Das besondere Lehramt der Kirche).

$8 \mathrm{KO}, 10$. 
katolikom zarzucają niektórzy protestanci - za „namiastkę” Chrystusa, zastępującą źródła - Pismo św. i Tradycję ${ }^{9}$.

W szczególności Urząd Nauczycielski ,,z rozkazu Bożego i przy pomocy Ducha Świętego słucha pobożnie Słowa Bożego, święcie go strzeże i wiernie wyjaśnia. I wszystko, co podaje do wierzenia jako objawione przez Boga, czerpie z tego jednego depozytu wiary” ${ }^{10}$. Sformułowanie ,pobożnie słucha" stanowi w przytoczonym tekście pewne novum, wprowadzone przez Konstytucję Dei verbum. Natomiast dwa następne obowiązki Magisterium, mianowicie konieczność „,́́więtego strzeżenia” i „wiernego wyjaśniania" Słowa Bożego, występowały już wielokrotnie w różnych dokumentach kościelnych ${ }^{11}$. Zwraca wreszcie uwagę milczenie soborowej wypowiedzi w kwestii piętnowania i zwalczania przez Urząd Nauczycielski błędów zagrażających objawionej wierze ${ }^{12}$.

Rola, którą spełnia Magisterium w odniesieniu do Objawienia jest więc silnie zróżnicowana i niezwykle odpowiedzialna. Depozyt wiary, który znajduje się w Piśmie św. i Tradycji, definitywnie zakończony w Chrystusie i ze śmiercią apostołów, nie może ulec istotnej zmianie: pomniejszeniu lub poszerzeniu ${ }^{13}$. Pomimo to - jak wiadomo - istnieje rozwój dogmatów, czyli postęp w interpretacji Objawienia. Co on zatem oznacza, skoro nie wnosi zasadniczych zmian w objawionej nauce wiary i moralności? - Po prostu, stanowi tylko lepszą percepcję i głębsze zrozumienie objawionej treści przez Lud Boży. Poszczególne epoki przynoszą bowiem ze sobą nowe odkrycia i naświetlenia, dzięki którym ujawniają się ukryte szczegóły, a niejasności stają się zrozumiałe. Wskutek

9 G. Ebeling, Die Geschichtlichkeit der Kirche und ihrer Verkündigung als theologisches Problem in drei Vorlesungen, Tübingen, 1954, 44-50. - H. von Loewenich, Der moderne Katholizismus, Witten, 1955, 160-166. - W. Schweitzer, Schrift und Dogma in der Oekumene, Gütersloh, 1953, 32-52. Cyt. za Latourelle, Théologie de la Révélation, 493.

$10 \mathrm{KO}, 10$.

11 Np. Ep. „Dat mihi” ad Venerium episc. Mediolan., cc. 401: DS (93) 209. Conc. Tridentinum, Decretum de iustificatione: DS (792a) 1520. - Ep. „Tuas libenter" ad archiep. Monaco-Frisingensem, 21. Dec. 1863: DS (1679) 2875. - Conc. Vaticanum I, Constitutio dogmatica „Dei Filius” de fide catholica: DS (1781) 3000: ,innixi Dei Verbo scripto et tradito, prout ab Ecclesia catholica sancte custoditum et genuine expositum"; - por. tamże DS (1800) 3020: „tradita, fideliter custodienda et infallibiliter declaranda" oraz Constitutio dogmatica I "Pastor aeternus" de Ecclesia Christi: DS (1836) 3069. - Litt. motu proprio "Sacrorum antistitum", 1. Sept. 1910: DS (2145) 3541. - Litt. encycl. „Humani generis”: DS (2313) 3884-3885; (2314) 3886; (2315) 3887: ,totius depositi veritatis divinitus revelatae custos ac interpres".

12 Latourelle, Théologie de la Révélation, 367-369; 377-379.

13 ,Nullum sane inventum inducitur nec quidquam additur novi ad earum summam veritatum, quae in deposito revelationis, Ecclesiae divinitus tradito, saltem implicite continentur", Litt. encycl. „Mortalium animos”, 6. Ian. 1928: DS, 3683. - Por. K. Rahner - K. Lehmann, Geschichtlichkeit der Vermittlung, w: Mysterium Salutis, Bd 1: Die Grundlagen heilsgeschichflicher Dogmatik, 727-776 (Das Problem der Dogmenentwicklung); 776-782 (Die Bedeutung der Dogmengeschichte); 783-787 (Bibliographie). 
tego Kościół musi ciągle od nowa odczytywać objawioną treść uwzględniając postęp naszego poznania. Ów proces, coraz pełniejszego zgłębiania i asymilacji przekazanego Słowa Bożego znalazł swoje klasyczne sformułowanie już u św. Wincentego z Lerynu: ,Niechże więc wzrasta i olbrzymie nawet postępy czyni zrozumienie, wiedza, mądrość tak w każdym z osobna, jak u ogółu, tak w jednostce, jak w całym Kościele, według poziomu lat i wieków, ale koniecznie w swojej jakości, to jest w obrębie tego samego dogmatu, w tym samym duchu, w tym samym znaczeniu" 14 . Okazją, czy przyczyną, tego rozwoju doktrynalnego mogą być prześladowania, błędnowierstwo, kontrowersje teologiczne, postęp nauki, prywatne objawienia itp. Zresztą, każdy okres historii Kościoła posiada pod tym względem własne doświadczenia. Urząd Nauczycielski, przez swoją autentyczną interpretacje, ma więc za zadanie kontrolę tego procesu, czyli powinien strzec i bronić przed deformacjami objawiony depozyt wiary. W tej pracy - z woli Bożej - cieszy się charyzmatem nieomylności, tzn. specjalną asystencją Ducha Swiętego. Stanowi ona istotny element rozwoju dogmatów, bo nie tylko chroni Kościół przed zbłądzeniem, lecz także prowadzi go do poznania pełnej prawdy ${ }^{15}$.

Ta obecność i działalność Ducha Świętego ujawnia się w całym Kościele. Konstytucja dogmatyczna o Kościele II Soboru Watykańskiego mówi wyraźnie o ,ogóle wiernych mających namaszczenie od Świętego (por. 1 J 2, 10 i 27), które gwarantuje niezbłądzalność ,nadprzyrodzonego zmysłu wiary" w Ludzie Bożym ${ }^{16}$. Obecności Ducha Świętego nie jest także pozbawiona praca teologów, która zgłębia i systematyzuje dane Objawienia. Asystencja Ducha Świętego, z jaką w tym wypadku mamy do czynienia, jest jednak jakościowo różna od tej, która otacza Urząd Nauczycielski Kościoła ${ }^{17}$. Stąd błędne są sugestie, że w sytuacjach konfliktowych pomiędzy Magisterium authenticum i teologami powinna decydować tylko siła argumentacji 18. Wolność poszukiwań teologicznych

14 Pamiętnik. Commonitorium. Przełożył, wstęp i objaśnienia dał J. Stahr, Poznań, 1928, 43.

15 Latourelle, Théologie de la Révélation, 492-498.

$16 \mathrm{KK}, 12$. Tekst lacińsko-polski Lumen gentium znajduje się w: Sobór Watykański II, 146-265.

17 G. Thils mówi, że z woli Chrystusa, ,peuple chrétien est 'structuré' par les charismes divers de l'Esprit', L'infaillibilité de l'Église 'in credendo' et 'in docendo', w: De doctrina Concilii Vaticani Primi, Libreria Editrice Vaticana, 1969, 558. Por. B. Studer, Träger der Vermittlung, w: Mysterium Salutis, Bd 1: Die Grundlagen heilsgeschichtiicher Dogmatik, 600-604 (Die Theologen).

18 E. Gutwenger, Welche Rolle spielt das Magisterium im Glauben der Kirchengemeinschaft, "Concilium" (niem.), 1 (1970) 18-25. Zwłaszcza dwa teksty są charakterystyczne: „Die logische Ehrlikeit verlangt zu sagen, dass Äusserungen des magisterium authenticum im letzten Grunde Einladungen zum Dialog sind, in welchem das Gewicht der Argumente einer Klärung zugeführt wird", s. 23-24; „Logisch unhaltbar ist es, wenn eine Institution sich als fehlbare einschaltet und 
w Kościele nie ma charakteru absolutnego, jest wolnością względną, która musi się liczyć ze wspólną wiarą Ludu Bożego, będącą dziełem Ducha Świętego, i tę wiarę, w znaczeniu ustalonym przez Magisterium, respektować.

W sumie Objawienie, mieszczące się w Tradycji i Piśmie św., oraz Magisterium stanowią z woli Bożej jedną zwartą całość i „tak ściśle ze sobą się łączą i zespalają, że jedno bez pozostałych nie może istnieć" ${ }^{19}$. Wszelkie próby sztucznego separowania tych rzeczywistości, z natury rzeczy komplementarnych, przynoszą ze sobą tylko ich zniekształcenie. Inaczej mówiąc, Słow o Boże dociera nieskażone do İudzi حrzez Pismośw., Tradycjęi Magisterium, choć w każdym wypadku w inny sposób. Pismo św. i Tradycja są normą wiary dalszą, Magisterium zaś jej normą bliższą ${ }^{20}$. Posłuszeństwo należne nauce Kościoła nie jest zatem w swych ostatecznych konsekwencjach podporządkowaniem się autorytetowi ludzkiemu, lecz powadze objawiającego się Boga przez Jezusa Chrystusa w Duchu Swiętym.

\section{PAPIESKI URZĄD NAUCZYCIELSKI}

Najbardziej podstawowy obowiązek Urzędu Nauczycielskiego Kościoła polega na autentycznym i nieomylnym nauczaniu Objawienia $\mathrm{w}$ imieniu i powagą samego Boga. W tym nauczaniu - choć stanowi ono zadanie całego Kościoła - nauczającej hierarchii przysługują z woli Chrystusa specjalne uprawnienia. Kolegium biskupie ze swoją głową papieżem, jako prawny następca dwunastu apostołów z Piotrem na czele, jest bowiem podmiotem najwyższej władzy nauczycielskiej w Kościele. Może ją sprawować bądź rozrzucone po świecie (Ecclesia dispersa), bądź też zebrane na soborze powszechnym (Ecclesia coadunata) ${ }^{21}$. Ale i sam papież, następca św. Piotra - i to również z woli Chrystusa - jest osobiście podmiotem najwyższej władzy nauczycielskiej Kościoła. Dzięki temu stanowi on

den Anschpruch erhebt, autoritär die Frage nach der Wahrheit regeln zu können. Das kann nur kraft der Gründe geschehen, die sie vorbringt. Es wäre begrüssenswert, wenn sich in solchen Fällen das Magisterium darauf beschränkte, in einen Dialog mit der Theologie einzutreten und eventuell ihre Gründe durch Gegengründe zu entkräften", s. 25. Polemizując z tą opinią bynajmniej nie chcę nie doceniać wartości i znaczenia argumentacji teologicznej. Pragnę tylko zwrócić uwagę na jej pomocniczy charakter. Ostateczną gwarancję prawdy nauczanej w Kościele stanowi bowiem wyłącznie sam Duch Swięty.

$19 \mathrm{KO}, 10$.

20 L. Boyer, Magistère ecclésiastique, w: Tenże, Dictionnaire théologique, Desclée, 1963, 406.

21 Por. P. Nau, Le magistère pontifical ordinaire au Premier Concile du Vatican, w: De doctrna Concilii Vaticani Primi, 167-168; 177-198. 
„,trwałą i widzialną zasadę i fundament jedności wiary i wspólnoty” 22. Owa ,personifikacja" Urzędu Nauczycielskiego w biskupie rzymskim należy to szczególniej podkreślić — nie oznacza jednak ani jego „wyłączności”, ani też ,wchłonięcia” kompetencji nauczycielskich episkopatu. Uprawnienia, jakie biskupi posiadają indywidualnie lub kolegialnie $\mathrm{w}$ zakresie nauczania pozostają $\mathrm{z}$ prawa Bożego nienaruszone. A zatem twierdzenie, że biskup rzymski sam osobiście jest także najwyższym nauczycielem nie ogranicza pełnomocnictw innych biskupów pod tym względem, lecz jedynie przyznaje mu te prerogatywy, którymi obdarza go to samo prawo Boże. Inaczej mówiąc, sam Chrystus zadecydował, że rzeczy tak się mają, aby w swym nauczaniu ,episkopat był jeden i niepodzielny" ${ }^{23}$.

Zasadniczo istnieją dwie formy nauczania papieskiego: uroczysta magisterium ni eomylne (infallibile) i zwykła - magisterium a utentyczne (authenticum). W chwili obecnej obie formy są przedmiotem wypowiedzi soborowych. Magisterium nieomylne zostało określone przez I Sobór Watykański w IV-tym rozdziale I Konstytucji dogmatycznej o Kościele Pastor aeternus ${ }^{24}$. Z kolei II Sobór Watykański w III rozdziale Konstytucji dogmatycznej o Kościele Lumen gentium $2 s$ podjął problematykę magisterium autentycznego. Obie wypowiedzi nie posiadają jednak równej rangi doktrynalnej, a zwłaszcza tej samej pewności teologicznej. Doktryna Vaticanum I jest dogmatem wiary. Vaticanum II podaje tylko naukę powszechnie przyjętą w Kościele bez ostatecznego zdefiniowania. Analiza teologiczna właśnie tych sformułowań soborowych będzie stanowić podstawe naszych wywodów na temat uroczystego i zwyczajnego nauczania papieży.

\section{A. Orzeczenia uroczyste}

Zanim przystąpimy do charakterystyki uroczystego nauczania biskupów rzymskich należy najpierw przytoczyć odnoszące się doń soborowe teksty.

22 ,perpetuum ac visibile unitatis fidei et communionis principium et fundamentum", KK, 18. Tłumaczenie polskie powyższego cytatu wykazuje istotny brak, ponieważ opuszczono słowo, wiara” (fidei). Por. Sobór Watykański II, 177. Należy jeszcze zauważyć, że stanowi on prawie dosłowne powtórzenie paralelnego tekstu z „Pastor aeternus” I Soboru Watykańskiego. DS (1821) 3050.

23 Tamże.

24 Sessio IV, 18. Iul. 1870: Constitutio dogmatica I „Pastor aeternus” de Ecclesia Christi: DS (1832) 3065 - (1840) 3075.

$25 \mathrm{KK}, 18-29$. 


\section{Vaticanum I:}

„Dlatego idąc wiernie w ślady Tradycji otrzymanej od początku wiary chrześcijańskiej, ku chwale Boga, ... za zgodą świętego Soboru nauczamy i definiujemy jako dogmat objawiony przez Boga, że Biskup Rzymski, gdy mówi ex cathedra - tzn. gdy sprawując urząd pasterza i nauczyciela wszystkich wiernych, swą najwyższą apostolską władzą określa zobowiązującą cały Kościół naukę w sprawach wiary i moralności dzięki opiece Bożej przyrzeczonej mu w osobie św. Piotra Apostoła, posiada tę nieomylność, jaką Boski Zbawiciel chciał, aby Kościół jego był obdarzony w definiowaniu nauki wiary i moralności. Toteż takie definicje są niezmienne same ze siebie, a nie na skutek zgody Kościoła” 26.

\section{Vaticanum II:}

„Nieomylnością... z tytułu swego urzędu cieszy się Biskup Rzymski, Głowa Kolegium Biskupiego, gdy jako najwyższy pasterz i nauczyciel wszystkich wiernych Chrystusowych, który braci swych umacnia w wierze (por. Łk 22, 32), ogłasza definitywnym aktem naukę dotyczącą wiary i obyczajów. Toteż orzeczenia jego słusznie zwane są nienaruszalnymi same $\mathrm{z}$ siebie, a nie na mocy zgody Kościoła, jako że ogłoszone zostały z pomocą Ducha Świętego przyrzeczoną mu w osobie św. Piotra i dlatego nie potrzebują niczyjej aprobaty ani nie dopuszczają odwoływania się do niczyjego sądu. Wówczas bowiem Biskup Rzymski nie wyraża sądu jako osoba prywatna, lecz jako najwyższy nauczyciel Kościola powszechnego, któremu przysługuje w szczególniejszy sposób charyzmat nieomylności samego Kościoła, wykłada naukę katolicką lub bierze ją w obronę" 27 .

1. Zwykłe porównanie przytoczonych tekstów wykazuje ich całkowitą zgodność treściową. Vaticanum II tylko powtarza i wyjaśnia definicję Vaticanum I. Wspomniane ,,wyjaśnienie” odnosi się w szczególności do dwóch kwestii.

$\mathrm{Na}$ samym początku po słowach: „Biskup Rzymski” zostało dodane: „Głowa Kolegium Biskupiego”. Otóż, wyrażenie to znalazło się w tekście, ponieważ wskazuje dlaczego przy omawianiu Urzędu Nauczycielskiego episkopatu poświęcono tak wiele miejsca nauczaniu papieża. Należy jednak uświadomić sobie dokładny sens załączonych słów. Stwierdzają one tylko organiczny związek następcy św. Piotra z kolegium. Nie mają nato-

26 DS (1839) 3073-3074. Tłum. polskie w: Breviarium fidei. Kodeks doktrynalnych wypowiedzi. Kościoła, oprac. J. M. Szymusiak - S. Głowa, Poznań $1964,114$.

27 KK, 25. - Zob. Sobór Watykański II, 191. 
miast znaczenia zawężającego, tzn. nie mówią, że papież cieszy się przywilejem nieomylności o tyle tylko, o ile jest głową Kolegium biskupów 28.

Główne „wyjaśnienie” Vaticanum II dotyczy zwrotu mówiącego, że definicje papieskie są ,niezmienne (nienaruszalne) same $z$ siebie a nie na skutek (mocy) zgody Kościoła" (ex sese, non autem ex consensu Ecclesiae, irreformabiles esse). Niekatolicy zarzucają tej formule, że stawia biskupa Rzymu poza i ponad Kościołem. Miałaby ona rzekomo pozwalać papieżowi nieomylnie definiować wszystko, co tylko mu się podoba, wprowadzać osobiste rozstrzygnięcia niezależnie od wiary Kościoła. Zachodziła więc konieczność uściślenia intencji Vaticanum I. Tekst Vaticanum II, precyzując je bliżej, wyjaśnia, iż biskup Rzymu nieodwołalnie określa jedynie prawdziwą wiarę Kościoła i to na mocy charyzmatu, który w swej najgłębszej istocie jest asystencją Ducha Swiętego, przyrzeczoną mu w osobie św. Piotra (Ek 22, 31-31). Dla tej właśnie a nie innej racji rozstrzygnięcia doktrynalne ex cathedra „,nie potrzebują niczyjej aprobaty ani nie dopuszczają odwoływania się do niczyjego sądu". W tej sytuacji bowiem nikomu na ziemi, nawet samemu papieżowi, nie wolno korygować, czy odrzucać definicji dogmatycznych. Tego rodzaju postępowanie równałoby się stawianiu autorytetu ludzkiego nad powagę samego Boga. Innymi słowy, orzeczenia ex cathedra nie są ,,aktem prywatnym" następcy św. Piotra, lecz aktem ,najwyższego nauczyciela Kościoła powszechnego". Z tego wynika, że w momencie definiowania biskup Rzymu posiada „charyzmat nieomylności samego Kościoła” i reprezentuje cały Kościół 29 .

2. Każda papieska definicja dogmatyczna musi spełniać szereg warunków. Oprócz warunków specjalnych, o których będzie osobno mowa, należy wymienić tzw. warunki ,elementarne”, powszechnie wymagane do ważności odpowiedzialnych decyzji. Tak np. jest konieczne, aby biskup rzymski, podejmując swe ostateczne rozstrzygnięcia doktrynalne, cieszył się odpowiednią wolnością. Są też takie warunki, które go zobowiązują od strony moralnej. Do nich należy z kolei zasięgnięcie wszechstronnej informacji $u$ biegłych i gruntowne studium problemu. Nie ulega wresz-

28 Relatio de n. 25, antea n. 19, w: Schema Constitutionis de Ecclesia (sub secreto), Typis Polyglottis Vaticanis, 1964, 97: „Ex una parte non habet valorem restrictivum: consulto enim non dicitur 'ut' vel 'quatenus' caput collegii; ex altera parte ordo idearum exigit hanc incisam, quia explicat quare in textu qui de munere docendi Episcoporum agit, tam fuse de potestate docendi Romani Pontificis fiat sermo".

29 Tamże, 97-98: „Haec autem congrua explicatio gradatim exhibetur: primo dicitur quaenam sit ratio formalis irreformabilitatis huiusmodi definitionum videlicet assistentia Spiritus Sancti singulariter Romano Pontifici in beato Petro promissa; secundo, indicantur duae consequentiae, non adaequate distinctae, illius irreformabilitatis, quibus fit ut dictae definitiones nulla aliorum approbatione indigeant, nec ullam ad alium iudicium (ne quidem ad aliud iudicium ipsius Romani Pontificis) appellationem patiantur". 
cie wątpliwości, że orzeczenie dogmatyczne powinno być wyraźne. Informuje o tym CIC (c. 1323, § 3): ,Za ogłoszoną, albo zdefiniowaną nie może być uznana żadna rzecz, o której jasno to nie zostało stwierdzone" ${ }^{30}$.

Definicja Vaticanum I, powtórzona w swej istocie przez Vaticanum II, zawiera ponadto trzy grupy specjalnych wymagań, które jednocześnie są konieczne, aby orzeczenie papieskie stało się dogmatem wiary. Dotyczą one: a) podmiotu samej nieomylności - osoby biskupa Rzymu; b) jej przedmiotu - nauki wiary i moralności obowiązującej Kościół powszechny; c) sposobu nauczania przez papieża - woli definiowania. Te trzy grupy warunków zostały szczególnie zaakcentowane, aby określić granice nieomylnego nauczania papieży i zabezpieczyć przed ewentualnymi nadużyciami ${ }^{31}$.

a. Przede wszystkim należy zauważyć, że nieomylność papieska ma charakter personalny, tzn. jest dana wszystkim pojedyńczym biskupom Rzymu, żadnego nie wykluczając ani pod względem chronologicznym, ani pod względem osobowości, która niekiedy może pozostawiać margines dla krytyki. Oznacza to, że nieomylność jest osobistym przywilejem biskupa Rzymu jako następcy św. Piotra i poprzez niego przysługuje stolicy rzymskiej, a nie odwrotnie. Niemniej obecnie papieże są nieomylni $\mathrm{z}$ racji swego urzędu biskupa Rzymu, ponieważ tylko ten urząd zapewnia im dziedzictwo św. Piotra i w konsekwencji funkcję głowy kolegium biskupów. Bycie nieomylnym wynika bowiem właśnie z tak pojętej pozycji papieża w hierarchii kościelnej, a nie z racji jego osobistych przymiotów, czy innych piastowanych godności (np. prymasa Włoch, patriarchy Zachodu, Władcy Państwa Kościelnego).

Ogłaszając dogmat papież powinien spełniać urząd pasterza i nauczyciela wszystkich wiernych Chrystusowych (cum omnium Christianorum pastoris et doctoris munere fungens) i angażować w najwyższym stopniu swój apostolski autorytet, czyli ten, który wyłącznie jemu samemu przysługuje (pro suprema sua apostolica auctoritate).

NieomyIność papieskiego nauczania ex cathedra poręcza sam Bóg, Prawda bezwzględna. Papieże mają zapewnioną wtedy - co już wyżej stwierdzono - tę samą pomoc Bożą, którą Chrystus przyrzekł św. Piotrowi (per assistentiam divinam ipsi in beato Petro promissam). Nie jest to jednak taka inspiracja, jaką cieszyli się natchnieni autorzy Pisma św. (2 Tm 3, 16: 2 P 1, 21); nie jest to także nowe Objawienie - uzupełnienie tego, które skończyło się wraz z ostatnim z apostołów. Mówiąc wyraźniej, stale obecny w Kościele Chrystus (Mt 28, 20) oraz opieka Ducha Swię-

30 Por. G. Thils, L'infaillibilité du Pape selon la définition de Vatican I, Louvain, 1968, 172-176.

31 U. Betti, Dottrina della Constituzione dommatica „Pastor aeternus”, w: De doctrina Concilii Vaticani Primi, 345; 359. 
tego (J 14, 26: 16, 13) gwarantują niezbłądzalność definicji dogmatycznych ${ }^{32}$.

b. Papieska nieomylność, uwarunkowana $z$ zewnątrz przez pomoc Bożą, stanowi przywilej podarowany. Jest darem Bożym. To jest przyczyną, że pozostaje istotnie ograniczona także w swoim przedmiocie. Nie może przekraczać granic wytkniętych jej przez Boga. Rozciąga się zatem tylko na „naukę wiary i moralności zobowiązującą cały Kościól” (doctrinam de fide vel moribus ab universa Ecclesia tenendam). Formuła powyższa obejmuje całą naukę chrześcijańską, zarówno spekulatywną jak i praktyczną, tj. prawdę i działanie ludzkie według wymagań Objawienia ${ }^{33}$.

Ponadto, zostało wyraźnie powiedziane na Vaticanum I, że nieomylność papieska pokrywa się co do natury i przedmiotu z nieomylnością Kościoła (ea infallibilitate pollere, qua divinus Redemptor Ecclesiam suam in definienda doctrina de fide vel moribus instructam esse voluit). Ta znowu - o czym z kolei naucza Vaticanum II — ,ma taki zakres, jak i depozyt boskiego Objawienia, który ma być ze czcią przechowywany i wiernie wyjaśniany" ${ }^{34}$. Oznacza to, że przedmiot nieomylności Kościoła jak i biskupa rzymskiego rozciąga się na wszystko, co albo wprost należy do objawionego depozytu (obiectum directum), albo jest bezwględnie konieczne do jego strzeżenia i tłumaczenia (obiectum indirectum) ${ }^{35}$.

Wreszcie należy podkreślić, że kwestia zdefiniowana przez papieża wchodzi z konieczności w zakres nieomylnego nauczania. Definiując, papież zakreśla granicę swej niemylności, która także należy do „,nauki wiary i moralności". Dopuszczenie bowiem możliwości osobnego rozstrzygania, czy przedmiot definicji dogmatycznej podpada pod przywilej nieomylności, czy też nie, w rzeczy samej przekreślałoby samą nieomylność ogłoszonych dogmatów ${ }^{36}$.

c. Nie każda jednak wypowiedź papieska na temat wiary i moralności jest nieomylna. Przywilej nieomylności przysługuje jej tylko wtedy,

32 Por. tamże, 345-354 (Requisiti nel sogetto). Mówiąc, że w momencie definiowania papież ma spełniać funkcję pasterza i nauczyciela wszystkich ,wiernych Chrystusowi" (Christifidelium) Vaticanum II zmieniło terminologię Vaticanum I, które posłużyło się w tym miejscu słowem „chrześcijan” (christianorum). Jako powód zmiany Relacja podaje używanie tej ostatniej nazwy przez prawosławnych i protestantów. Relatio de n. 25, antea n. 19, w: Schema Constitutionis de Ecclesia, 97.

33 Tamże, 354-358 (Requisiti nell'ogetto).

$34 \mathrm{KK}, 25$.

35. Relatio de n. 25, antea n. 19, w: Schema Constitutionis de Ecclesia, 97: ,ideoque extenditur ad ea omnia, et ad ea tantum, quae vel directe ad ipsum depositum revelatum spectant, vel quae ad idem depositum sancte custodiendum et fideliter exponendum requiruntur". Por. A. Lang. Der Auftrag der Kirche, München, ${ }^{3} 1962,249-255$.

${ }^{36}$ F. A. Sullivan, De Ecclesia. I. Quaestiones theologiae fundamentalis, Romae, 1963,322 . 
kiedy biskup rzymski przemawia ex cathedra, czyli definiuje (definit), a więc ogłasza ostateczne rozstrzygnięcie dolstrynalne, które zobowiązuje cały powszechny Kościół. Rodzaj dokumentu i forma zewnętrzna są obojętne, byleby tylko jasno i niedwuznacznie ukazywały u papieża intencję definiowania. Słowo „definiuje” w formule dogmatycznej Pastor aeternus nie ma więc zawężonego, wyłącznie prawnego sensu. Nie oznacza zatem jedynie rozporządzenia, które usuwa kontrowersje w ramach określonego tematu religijnego. Zawiera ono znacznie więcej. Wskazuje bowiem, że papież sam bezpośrednio „definitywnym aktem" — jak się wyraża Lumen gentium - podjął ostateczną decyzję w kwestii odnoszącej się do wiary lub moralności, dzięki której chrześcijanie bez większych trudności mogą rozpoznać w ,chaosie” błędnych poglądów, ortodoksyjną naukę ${ }^{37}$.

3. Jak wiadomo, II Sobór Watykański podniósł zagadnienie reinterpretacji doktryny katolickiej. W czasie inauguracji Soboru Jan XXIII wyraźnie o nim mówił. Jego zdaniem - Kościół powinien - oczywiście w ramach wierności dla depozytu wiary - przebadać swoje nauczanie i zapewnić mu taki wykład, który odpowiadałby obecnym czasom ${ }^{38}$. Tak sformułowany postulat doczekał się ,oficjalnej” realizacji już w samych dokumentach soborowych. Przyjęty przez nie sposób przedstawienia doktryny - nie tyle zobiektywizowany i transcendentny' co podmiotowy i psychologiczny - zbliża ją do człowieka ${ }^{39}$. Po soborze pojawiły się jednak także błędne próby radykalnej reinterpretacji, która zmienia nie tylko formę pojęciowo-literacką katolickiego Credo, lecz samą treść wiary ${ }^{40}$.

W tym kontekście wyraźniej narzuca się pytanie, jak należy rozumieć „niezmienność”, czy „nienaruszalność” (irreformabilitas) papieskich definicji dogmatycznych. Otóż, oznacza ona przede wszystkim, że raz na zawsze podjęte rozstrzygnięcia doktrynalne nigdy nie zostaną uznane przez Kościół za fałszywe. Kościół też w przyszłości nie ogłosi za prawdę niczego, co stałoby z nimi w sprzeczności. Równocześnie jednak należy podkreślić, że formuły dogmatyczne są mową ludzką o Słowie Bożym. Żadna natomiast mowa ludzka, nawet ta, którą asystencja Ducha Świę-

37 Betti, Dottrina della Costituzione dommatica „Pastor aeternus”, 358-359 (Requisiti nel modo d'insegnamento).

38 Summi Pontificis Joannis XXIII allocutio in solemni ss. Concilii inauguratione (Sessio I: d. 11 oct. 1962), w: Constitutiones - Decreta - Declarationes, Typis Polyglottis Vaticanis, 1966, 863-865.

39 Por. P. Parente, Il Concilio Vaticano I e il suo significato storico-dottrinale, „L'Osservatore Romano”, z dn. 9-10. XII 1969, 3, kol. 7: „Mentre il Vaticano I, come la teologia classica, è più oggettivo, più trascendente e quindi più distaccato dal mondo, che condanna, il Vaticano II è più soggetivo, più psicologico, più aderente alla realtà umana, nella quale si inserisce volentieri per dialogare col figliuol prodigo".

40 Por. I. Różycki, Początki ,nowej” teologii, „Studia theologica varsaviensia”, 7 (1969), nr 2, 49-103. 
tego ustrzegła od błędu, nie potrafi bez reszty wyczerpać objawionej prawdy Bożej i tak doskonale ją przedstawić, że już nigdy nic więcej lub lepiej nie można by na jej temat powiedzieć. Pod tym względem mogą więc być „ulepszane" i ,przystosowywane” do nowych sytuacji cywilizacyjno-kulturowych chrześcijan także nieomylne orzeczenia papieży. Ich „niezmienność" wyklucza bowiem tylko błąd w wierze, ale nie twierdzi, że dogmatyczne sformułowanie pod każdym względem jest odpowiednie, że doskonale wychodzi naprzeciw mentalności ludzkiej i że już nigdy nie zostanie zastąpione przez określenie lepsze. Reinterpretacja katolicka nie może jednak nigdy zmieniać tego sensu, jaki został nadany w momencie definiowania ${ }^{41}$.

4. Względem definicji dogmatycznych w ogóle, a papieskich w szczególności, obowiązuje chrześcijan posłuszeństwo boskiej i katolickiej wiary (fidei divinae et catholicae obsequium), czyli ze strony człowieka najwyższy stopień subordynacji religijnej objawiającemu się Bogu ${ }^{42}$. Kto się uchyla od tego posłuszeństwa, tym samym wyłącza się ze wspólnoty wierzących w Chrystusa. Formalna klątwa nie musi mieć tu miejsca. Dołączona do orzeczeń ex cathedra stwierdza tylko, co „odstępca”, sprzeniewierzając się dogmatowi, sam uczynił ${ }^{43}$. Charakterystyczne pod tym względem jest porównanie zobowiązań, jakie nakłada ludziom nieomylność w ujęciu Vaticanum I i II. Ukazuje ona bowiem zmianę stylu -- przy zachowaniu istoty rzeczy - w odnoszeniu się Kościoła do ludzi. I tak, potępiający kanon z Pastor aeternus: „Jeśli zaś ktoś, co nie daj Boże, odważy się tej naszej definicji przeciwstawić, niech będzie wyłączony ze społeczności wiernych" "44, został zastąpiony w Lumen gentium przez wykład pozytywny: „Orzeczeniom tym nie może nigdy zabraknąć zgody Kościoła, a to z powodu działania jednego i tego samego Ducha Swiętego, dzięki któremu to działaniu utrzymuje się w jedności wiary i czyni w niej postępy" "45. Tą drogą zostalo uchylone wrażenie, jakoby definicje dogmatyczne były wymuszane zewnętrznymi groźbami a nie stanowiły, z pomocą łaski Bożej, wspólnego wyrazu wewnętrznie motywowanej, jednomyślnej postawy religijnej Ludu Bożego.

Żądanie posłuszeństwa dla papieskich rozstrzygnięć doktrynalnych w swej najgłębszej istocie stanowi więc apel do opowiedzenia się po stronie prawdy, która objawiła się w Chrystusie; idzie więc po linii godności osoby ludzkiej, stworzonej przez Boga do czczenia go „w duchu

41 Sullivan, De Ecclesia, 321-322. - K. Rahner, Kommentar zum III. Kapitel, Artikel 18-27, LThK. Das zweite vatikanische Konzil, 1 (1966) 238-239.

42 Por. J. Saraiva Martins, Definizioni dogmatiche, w: Dizionario del Concilio Ecumenico Vaticano Secondo, Roma, 1969, 991.

${ }_{43}$ M. Schmaus, Katholische Dogmatik, Bd. III, 1: Die Lehre von der Kirche, München, ${ }^{3-5} 1958,812$.

44 DS (1840) 3075.

$45 \mathrm{KK}, 25$. 
i prawdzie" (J 4, 24). Opowiedzenie się za definicją dogmatyczną uwalnia człowieka jedynie od błędu - co odpowiada jego najgłębszym aspiracjom - i zapewnia mu właściwą orientację życia, które powinno być nastawione na Boga, Prawdę bezwzględną ${ }^{46}$.

5. Uroczystości z okazji setnej rocznicy Vaticanum I, jakie odbyły się w Rzymie, przyniosły ze sobą wspomnienie i ocenę jego doktrynalnego dorobku ${ }^{47}$. W szczególności, nie zapomniano o dogmacie nieomylności papieskiej, który wtedy został zdefiniowany. Jak powiedział papież Paweł VI ,dotyczy on decydującego punktu w życiu Kościoła, prawdy objawionej, i odnosi się do wszystkich chrześcijan i całego świata. Dzisiaj, bardziej niż kiedykolwiek, jesteśmy tym zainteresowani" ${ }^{48}$. Narzuca się pytanie - dlaczego? Odpowiedź tutaj nie nastręcza większych trudności. W aktualnej, pełnej napięć sytuacji Kościoła, nieomylne magisterium biskupa rzymskiego odgrywa bardzo ważną rolę jako główny element i podstawa ,jedności wiary i wspólnoty” katolickiej. Niewątpliwie przyczynia się ono $\mathrm{w}$ sposób zasadniczy, i to zarówno u pasterzy jak i katolików świeckich, do zachowania ortodoksji katolickiej w sprawach wiary i moralności. Stąd rodzi się właśnie jego wielka aktualność.

\section{B. Nauczanie zwyczajne}

Żywy Urząd Nauczycielski Kościoła, przekazując wiernie objawiony depozyt wiary, rzadko posługuje się najwyższym, nieomylnym stopniem swego autorytetu doktrynalnego. Definitywne rozstrzyganie swych problemów religijnych Kościół stosuje z reguły najczęściej na soborach i to dla poważnych racji. W wypadku papieży miało to miejsce np. przy dogmatyzacji Niepokalanego Poczęcia ${ }^{49}$ i Wniebowzięcia 50 N.M.P. Normalnie kościelny Urząd Nauczycielski interweniuje jako magisterium zwyczajne, tzn. autorytatywnie, ale bez wykluczenia dal-

46 Schmaus, Katholische Dogmatik, Bd. III, 1: Die Lehre von der Kirche, 813.

47 Należy tutaj wymienić ceremonię jubileuszową $\mathrm{z}$ uczestnictwem papieża Pawła VI, w czasie której wyglosił referat kard. P. Parente. Por. przypis 39. Nadto Watykańska Księgarnia Wydawnicza opublikowała drukiem książkę pt. De doctrina Concilii Vaticani Primi, 1969, która zawiera zbiór wybranych studiów z lat 1948-1964, poświęconych dokumentom uchwalonym na I Soborze Watykańskim, a mianowicie: Konstytucji dogmatycznej „Dei Filius” o wierze katolickiej oraz Konstytucji dogmatycznej I „Pastor aeternus” o Kościele Chrystusowym. Niektóre $z$ tych studiów cytujemy i w niniejszej rozprawie. Por. przypisy: 17; 21; $31 ; 32 ; 33 ; 37$.

48 „Quello dell'infallibilità... tocca un punto decisivo della vita della Chiesa, di tutti i Christiani e del mondo, quello della Verità rivelata. Tutti, oggi più che mai, vi siamo interessati", Paulo VI all'udienza generale: Attualità del Concilio Vaticano I nella realtà storica contemporanea, "L'Osservatore Romano", z dn. 11. XII 1969, 1, kol. 4.

49 Bulia „Ineffabilis Deus”, 8. Dec. 1854: DS (1641) 2800-2804.

50 Const. Ap. „Munificentissimus Deus”, 1 Nov. 1950: DS (2331-2333) 3900-3904. 
szego zgłębiania kwestii. Również to zwyczajne nauczanie biskupów rzymskich ma szczególne znaczenie w przekazywaniu Objawienia zawartego w Piśmie św. i Tradycji; bowiem na co dzień stanowi organ najwyższej władzy nauczycielskiej w Kościele, mimo iż nie jest sprawowane w najwyższym wymiarze.

Dwie oficjalne wypowiedzi dotyczą głównie tego nauczania biskupa rzymskiego. Jedna pochodzi od Piusa XII, druga ma za autora Vaticanum II. Ponieważ będą stanowić przedmiot naszych zainteresowań, przytoczymy je w całości.

Encyklika Humani generis:

„Nie trzeba też sądzić, że pouczenia zawarte $\mathrm{w}$ encyklikach nie wymagają same przez się wewnętrznego poddania dlatego, że papieże nie występują co do nich z najwyższą nauczycielską powagą. Albowiem i te rzeczy są przedmiotem tego zwyczajnego nauczania, do którego także odnoszą się słowa: „Kto was słucha, mnie słucha" (Ek 10, 16), i często to, co w encyklikach wykłada się i z naciskiem podkreśla, to zazwyczaj już skądinąd do nauki katolickiej należy. Jeżeli zaś najwyżsi Pasterze w dokumentach swoich o jakiejś kwestii dotychczas dyskutowanej dają rostrzygające wyjaśnienie, dla wszystkich staje się jasnym, że według myśli i woli papieży, nie wolno już uważać tej kwestii za rzecz podlegającą swobodnej dyskusji teologów" 51.
Konstytucja Lumen gentium:

„Tę zaś zbożną uległość woli i rozumu w sposób szczególny okazywać należy autentycznemu urzędowi nauczycielskiemu Biskupa Rzymskiego nawet wtedy, gdy nie przemawia on ex cathedra; trzeba mianowicie ze czcią uznawać jego najwyższy urząd nauczycielski i do orzeczeń przez niego wypowiedzianych stosować się szczerze, zgodnie z jego myślą i wolą, która ujawnia się szczególnie, bądź przez charakter dokumentów, bądź przez częste podawanie tej samej nauki, bądź przez sam sposób jej wyrażania" 52 .

Problematyka zawarta $\mathrm{w}$ powyższych tekstach ma istotne znaczenie dla wiary chrześcijan i życia Kościoła.

1. Magisterium zwyczajne papieży zna różne formy ekspresji. Jedną

51 Litt. encycl. „Humani generis”, 12 Aug. 1950: DS (2313) 3885. Tłumaczenie polskie w: Breviarium fidei, 130.

52 KK, 25. - Zob. Sobór Watykański II, 191. 
z najstarszych wśród nich jest wy znanie wiary, czyli Credo ${ }^{53}$. Ostatnio posłużył się nim również Paweł VI. ${ }^{54}$ Następnie należy wymienić e n c y kliki, tzn. pisma papieskie skierowane przede wszystkim do biskupów całego świata, choć mogą one być adresowane i do węższego lub szerszego grona osób. Jan XXIII np. między adresatami swojej encykliki Pacem in terris wymienia także ,wszystkich ludzi dobrej woli" 55 . Częste posługiwanie się encyklikami rozpoczął papież Grzegorz XVI (1831-1846) a upowszechnił Leon XIII (1878-1903) ${ }^{56}$. Czy po II Soborze Watykańskim wchodzimy w okres ,zmierzchu” encyklik, trudno powiedzieć. Jest jednak oczywiste, że Paweł VI posługuje się nimi znacznie rzadziej, niż jego poprzednicy. Obecnie natomiast wysuwają się na czoło przemówienia papieski e, wygłaszane przy różnych okazjach. Wśród nich na specjalną uwagę zasługują regularne środowe przemówienia na audiencjach generalnych oraz przemówienia skierowane do określonych grup ludzi, składających ,wizytę” papieżowi. Ponieważ są one pozytywnym wykładem wiary, zawieraja przemyślane i trwałe treści religijne.

Oczywiście kościelne życie zna jeszcze wiele innych form, za pomocą których papieże przedstawiają swoje zarządzenia i doktrynę. Szczególnej wzmianki domagają się tutaj akty dykasterii rzymskich, a zwłaszcza d ekrety Kongregacji Nauki Wiary i Papieskiej Komis ji Biblijnej. Także dokumenty innych organów Stolicy Apostolskiej mogą ubocznie zawierać elementy doktrynalne. Przy aktach takich należy bardzo uważać na aprobatę papieską. Może być ona ogólna (in forma communi), jak to ma miejsce np. przy formule: de mandato Summi Pontificis. Wtedy zatwierdzony dokument formalnie jest aktem odnośnej dykasterii. Inaczej rzecz się ma, gdy zatwierdzenie, posługując się takimi formułami jak: de motu proprio; certa scientia; de apostolica auctoritatis plenitudine, ma charakter specjalny (in forma specifica). Tego rodzaju akty uchodzą za papieskie ${ }^{57}$.

Zasadniczym celem zwykłego nauczania papieży - obojętnie jaka byłaby forma - jest podawanie i to zarówno episkopatowi jak i katoli-

53 A. Brekelmans, Glaubensbekentnisse in der alten Kirche: Entstehung und Funktion, "Concilium", 1 (1970) 14-18. - Ks. H. Bogacki wyliczając , akty formalne, których autorem jest sam Papież" i przez które wyraża swe nauczanie zwyczajne, nie wzmiankuje formy Credo. Postuszeñstwo należne papieskiemu nauczaniu zwyczajnemu, „Roczniki teologiczno-kanoniczne”, 9 (1962), z. 2, s. 9. Crédo jednak z całą pewnością należy do wymienionych aktów formalnych papieży. Ks. Bogacki pominął je chyba ze względu na rzadkość występowania.

54 Sollemnis professio fidei, AAS, 60 (1968) 433-445.

55 Litt. encycl. „Pacem in terris", 11. Apr. 1963: AAS, 55 (1963) 257-304.

56 H. Bacht, Enzyklika, LThK, 3 (21959) 910-911.

57 Löhrer, Träger der Vermittlung, 184-185 (Das Lehramt des Paptes). Por. gruntowny wykład na ten temat u Sullivana, De Ecclesia, 355-359 (Scholion: De decretis Sancti Officii et Commissionis de Re Biblica). 
kom świeckim, wszystkiego, czego domaga się misja zbawcza Kościoła. Depozyt wiary, nienaruszony $\mathrm{w}$ swych elementach konstytutywnych i trwałych, jest tu adaptowany do ciągle zmieniających się okoliczności, różnych epok i miejsc.

2. Jak wiadomo, nie wszystkie prawdy religijne i zasady moralne, uznane w Kościele, mają jednakowy stopień pewności teologicznej. Główną przyczyną tego stanu rzeczy jest fakt, że różny jest ich stosunek do Objawienia Bożego. I tak, jedne z nich znajdują się tam wyraźnie, inne znowu wynikają zeń z mniejszą lub większą oczywistością. W zależności od rodzaju wzajemnych powiązań teologowie wyróżniają różne typy zdań objawionych.

W tej sytuacji, Urzędowi Nauczycielskiemu Kościoła zarówno biskupów jak i papieża — o czym była obszerniej mowa wyżej — przypada niezwykle doniosła rola $w$ autentycznej interpretacji Objawienia. Urząd ten ma bowiem prawo i obowiązek wydawać sądy. o wielu sprawach z Objawieniem związanych. Przede wszystkim rozstrzyga on, co jest objawione, a co nie. Następnie wyciąga wnioski z Objawienia i precyzuje, które twierdzenia są z nim nierozerwalnie złączone. Wreszcie może się wypowiadać na temat istniejących relacji pomiędzy Objawieniem i naturalnym poznaniem.

Należy jednak podkreślić, że istnieją różne formy i stopnie zaangażowania się ze strony Urzędu Nauczycielskiego Kościoła w wiarygodny wykład objawionego depozytu. Może być ono uroczyste i bezwzględnie nieomylne, jak przy definicjach dogmatycznych, które precyzują, że jakaś prawda została przez Boga objawiona i stanowi konieczny przedmiot wiary. Ale najczęściej bywa zwykłe i względnie omylne, tzn., że nie wyklucza pod każdym względem możliwości pomyłki i dalszych korektur. Przy ustalaniu wartości doktrynalnej jakiegoś twierdzenia teologicznego powinno się więc zbadać, z jakim stopniem zaangażowania ma się do czynienia w danym wypadku.

Odnosi się to szczególnie do nauczania zwyczajnego papieży. Jako biskupi rzymscy są oni $\mathrm{w}$ swoim urzędzie zastępcami Chrystusa i następcami św. Piotra. Pełnią funkcję głowy całego Kościoła oraz ojca wszystkich chrześcijan, z władzą pasterza i rządcy nad całym Kościołem. Jako najwyżsi nauczyciele nieomylnego w wierze Kościoła cieszą się przywilejem nieomylności, gdy przemawiają ex cathedra. Wszystko to razem sprawia, że zaangażowanie ich autorytetu doktrynalnego w nauczanie kościelne ma istotne znaczenie dla jego kwalifikacji teologicznej ${ }^{58}$.

Dopiero na tak zarysowanym tle staje się zrozumiałe, co mówi o po-

58 A. Kubiś, Kwalifikacja teologiczna wyznania wiary Pawta VI, „Analecta Cracoviensia", 1 (1969) 183-185. 
wadze magisterium zwyczajnego biskupów rzymskich encyklika Humani generis, a mianowicie, że zawarte w nim „rozstrzygające wyjaśnienie jakiejś kwestii" nie podlega już całkiem „,swobodnej dyskusji teologów”.

Nie wolno jednak nie zwrócić uwagi na fakt, że kwalifikacja teologiczna nauczania zwyczajnego papieży stanowi niezwykle trudne zadanie. Jest tak dlatego, ponieważ wiarygodność ich twierdzeń w poszczególnych kwestiach wykazuje dużą skalę rozpiętości. Są wypadki, kiedy daje ona całkowitą pewność moralną i wówczas jest nieomylna, choć brak jej jeszcze formalnego zdefiniowania ${ }^{59}$. Ale też nie da się $w$ tym nauczaniu absolutnie wykluczyć wszelkiego błędu, zwłaszcza gdy przytacza ono mniej lub więcej uzasadnione opinie teologiczne na ich własny ,rachunek", bez zajęcia zdecydowanie własnego stanowiska. Stąd przy ocenie papieskiego nauczania autentycznego należy postępować z daleko posuniętą ostrożnością i unikać zarówno przesadnych ocen jak i z góry powziętych uprzedzeń. Konstytucja dogmatyczna Lumen gentium wskazuje teologom na niektóre kryteria ułatwiające rozpoznanie pewności telogicznej jego twierdzeń. Są nimi: charakter dokumentów (indoles documentorum), częste podawanie nauki (frequens propositio), sposób jejwyrażania (ratio dicendi). Wszystkie te czynniki ułatwiają dokładniejsze odczytanie intencji i woli papieża oraz pozwalają ustalić stopień jego zaangażowania doktrynalnego $\mathrm{w}$ nauczanych kwestiach.

Papież sprawuje najczęściej rolę protektora względem objawionego depozytu, troszcząc się o jego rozpowszechnianie i wcielanie w życie. Ale nierzadko papieska opieka jest także akcją obronną, tzn. przeszkadza rozdarciu wiary, względnie troszczy się o przywrócenie naruszonej wspólnoty. Obie te funkcje stanowią dla biskupów nieodzowną pomoc w spełnianiu jednego $\mathrm{z}$ ich najbardziej podstawowych obowiązków, którym jest „umacnianie i strzeżenie jedności wiary i wspólnej dyscypliny całego Kościoła" ${ }^{60}$.

W pewnych momentach powyższe funkcje mogą się okazać bardzo niepopularne. Oznaczać to będzie jednak, że są autentycznie ewangeliczne właśnie ze względu na swą niepopularność. Urząd zastępcy Chrystusa

59 Liczba teologów, którzy bronią nieomylności zwyczajnego nauczania papieskiego ostatnimi laty bardzo się zwiększyła. Długą ich listę cytuje M. Caudron, Magistere ordinaire et infaillibilité pontificale d'après la Constitution "Dei filius" w: De doctrina Concilii Vaticani Primi, 122-123, przypis 1. G. Thils wydaje się nie podzielać ich opinii: ',Concluons. Jusqu'à mieux informé et jusqu'à preuve du contraire, nous croyons devoir défendre la doctrine selon laquelle le magistère pontifical ne jouit de l'assistance divine qui préserve d'erreur son jugement dogmatique, que lorsque le Pape définit ex cathedra, en donnant à cette expression toute la signification précise et technique qu'elle avait pour les Pères du concile”, „L'infaillibilité du Pape selon la définition de Vatican I, 225.

$60 \mathrm{KK}, 23$ : „Debent enim omnes Episcopi promovere et tueri unitatem fidei et disciplinam cunctae Ecclesiae communem", Sobór Watykański II, 186. 
będącego znakiem sprzeciwu (Łk 2, 34), jest niejako przez swoją naturę skazany na kontestację ${ }^{\text {f1. }}$.

3. Swoją moc zobowiązującą zwyczajne nauczanie biskupów rzymskich czerpie glówhie z misji pochodzącej od Chrystusa (Mt 16, 17-19; Ek 22, $31-32 ; J 21,15-17$ ), a nie $z$ argumentacji, jaką się posługuje. Zresztą i każda inna interwencja władzy kościelnej w kwestiach doktrynalnych, opierając się także na misji danej przez Chrystusa (Mt 18, 18; 28, 20), choć nie jest definicją dogmatyczną, a więc na niższym stopniu angażuje autorytet pasterski, posiada ten sam charakter. Chrystus bowiem upoważnił hierarchię, biskupów i papieża, do mówienia w swoim imieniu. On sam bierze ostateczną odpowiedzialność za jej nauczanie. Czyni to głównie przy pomocy posłanego przez siebie Ducha Świętego ( $J$ 14, 26; $16,13 ; \mathrm{Dz} 15,28)^{62}$.

Z tej przyczyny - należy to jeszcze raz z całą siłą podkreślić porównywanie nauczania zwyczajnego z wynikami dyskusji naukowych, nie dla zgłębienia i wszechstronnego ujęcia, lecz dla podważenia słuszności jego twierdzeń, jest z gruntu niewłaściwe i może okazać się zupełnie błędne. Oczywiście rzeczy się tak mają nie dlatego, by głębokie studium teologiczne nie przedstawialo żadnej wartości ${ }^{63}$, lecz dlatego, że pewność, jaką poręcza swemu nauczaniu należy do istotowo różnej kategorii w porównaniu z pewnością, którą daje Magisterium kościeine. Rozprawa naukowa poręcza tylko pewność ludzką, a więc z natury swej względną i omylną, gdy tymczasem pewność autentycznego nauczania należy do całkiem innego rzędu, ma za sobą autorytet Boży, Prawdę bezwzględną. Porównując zatem jedną z drugą należy zdać sobie sprawę z głębokich różnic, jakie je oddzielają i wykazać dużą oględność w formułowaniu ostatecznych wniosków ${ }^{64}$.

4. Na doktrynalne decyzje zwyczajnego nauczania papieskiego chrześcijanie, a tym bardziej katolicy, powinni odpowiedzieć nie tylko wstrzymaniem się od krytyki, zewnętrznym podporządkowaniem (silentium obsequiosum), lecz także wewnętrzną aprobatą (obsequium fidei). Ponieważ jednak róznią się one od definicji dogmatycznych, zgoda ze strony wiernych $w$ tym wypadku ma nieco inny charakter. Nauczanie uroczyste żąda dla swej treści - jak widzieliśmy - bezwzględnego posłuszeństwa

61 Betti, Il magistero del Romano Pontefice, „LOSservatore Romano”, z dn. 4 IV 1970, 2, kol. 2.

62 G. Vodopivec, Magistero, w: Dizionario del Concilio Ecumenico Vaticano Secondo, Roma, 1969, 1354-1355.

63 To wlaśnie studium ma na myśli Konstytucja Lumen gentium, gdy wzywa hierarchię, papieża i biskupów, do stosowania apta media (odpowiednich środków) przy przekazywaniu Objawienia. KK, 25.

64 Por. doskonale na ten temat uwagi w cyt. art. ks. Różyckiego o teologicznej pewności norm etycznych w encyklice „Humanae vitae" (przypis 1). Por. także przypis 18 . 
wiary $\mathrm{i}$ to do tego stopnia, że ten kto je odrzuca znajduje się poza ortodoksją. Jeżeli idzie o nauczanie zwyczajne, to należne mu posłuszeństwo opiera się także na motywacji płynącej $z$ wiary, ale nie posiada bezwarunkowego charakteru; encyklika Humani generis nazywa je ,wewnetrznym poddaniem" (assensus) poręczonym przez slowa Chrystusa: ,Kto was slucha, mnie slucha, a kto wami gardzi, mną gardzi” (Łk 10, 16), a Konstytucja Lumen gentium wzywa względem niego ,w sposób szczególny do religijnej uległości woli i rozumu" (religiosum animi obsequium), ponieważ trzeba, ,najwyższy Urząd Nauczycielski biskupa rzymskiego ze czcią uznawac i do jego orzeczeń szczerze się stosować”. Posłuszeństwo zwyczajnemu nauczaniu papieskiemu jest zatem afirmatywnym aktem religijnym o uległości zarówno wewn€̨trznej jak i zewnętrznej, który zresztą nie wyklucza jakościowo zróżniccwanego podporządkowania w zależności od swojej pewności teologicznej opartej przede wszystkim na zwiąku odnośnej prawdy religijnej, czy zasady moralnej z Objawieniem Bożym ${ }^{65}$. Kto więc nie akceptuje nauczania zwyczajnego w te $j$ mierze, jak tego żąda papie ż, z całą pewnością nie jest dobrym katolikiem ${ }^{66}$.

Objawienie - jak już powiedzieliśmy - domaga się istnienia Magisterium kościelnego głównie ze wzgledu na swój kontekst historyczny, który włącza depozyt wiary w proces ciągłych zmian, jakie dokonywaja się w świecie i ludziach. Słowo Boże, wcielając się w coraz to nowa rzeczywistośc ziemske, powinno bowiem zachowac swój pierwotny sens. Magisterium kościelne w oparciu o autorytet Boży zapewnia Objawieniu w historycznej zmienności nienaruszalność treściową ${ }^{67}$. Tẹ samą rolę wzgledem Objawienia Bożego pełni nie tyiko uroczyste, lecz także zwyczajne magisterium biskupa rzymskiego. Czuwając nad historycznym procesem asymilacji i akomodacji wiecznych wartości do ciagle zmieniających się warunków egzystencji ludzkiej gwarantuje mu nieskażoność w kontynuacji. Magisterium to ukazuje się nam jako tkanka lączna

65 Relatio de n. 25, antea n. 19, w: Schema Constitutionis de Ecclesia, 96-97: „Quod quidem fidei obsequium gradus diversos admittit iuxta maiorem vel minorem relationem veritatis divinae cum divina Revelatione".

60 Zostało podkreślone ,w tej mierze, jak tego żąda papież”, ponieważ „la tradizione teologica è constante nell'affermare la possibilità d'un futuro giudizio differente dell' autorità stessa ed anche la possibilità della esenzione dall'assentimento per chi, conoscendo a fondo la questione in proposito, ha ragioni veramente serie e proporzionatamente gravi per un giudizio diverso, basato su elementi nuovi tali che prima non sono stati abbastanza considerati: Tuttavia è più che chiaro che simili discussioni non devono trovar posto né ne1la predicazione né nella catechesi", Vodopivec, Magistero, 1354. - Por. Löhrer, Träger der Vermittlung, 585. -- Rahner, Kommentar zum III. Kapitel, Artikel 18-27, 235. MI. Bourke, Soll die Kirche Glaubensabweichungen mit Sanktionen belegen, ,Concilium", 1 (1970) 8-13.

${ }^{6} 7$ Latourelle, Théologie de la Révélation, 417-434 (Histoire et Révélation). 
całego Ludu Bożego, ponieważ przy ciągłym wzroście zapewnia Kościolowi tożsamość ze swymi początkami ${ }^{68}$. Innymi słowy, pomaga mu być zawsze ową jedyną w swoim rodzaju, bosko-ludzką społecznością, identyczną z tą, w której kiedyś wszyscy tworzyli jedno serce i jedną duszę, dzięki trwaniu w nauce apostołów i we wspólnocie braterskiej łamania chleba i modlitwy (Dz 2, 42; 4, 32). Jest to tkanka łączna, którą Chrystus łaskawie zostawił a Piotr i papieże, jego następcy, troskliwie ożywiają w organiźmie Ciała Mistycznego. Ta misja jest równocześnie, pod opieką Ducha Świętego, ich służbą Kościołowi.

68 Betti, Il magistero del Romano Pontefice, 2, kol. 2.

\section{R É S M E}

\section{LE MAGISTERE PONTIFICAL SELON LES \\ I ET II CONCILES DE VATICAN}

Les évéments qui ont lieu aujourd'hui dans l'Eglise catholique mettent en reìief limportance doctrinale du magistère papal. L'Auteur prend en considération ce sujet à la lumière des I et II Conciles de Vatican.

Le dépôt révélé, contenu dans l'Ecriture Sainte et dans la Tradition, a été confié à l'Eglise tout entière pour qu'elle en vive. Toutefois, son inteprétation authentique appartient exclusivement au magistère de l'Eglise. De façon générale, il faut dire que le magistère n'est pas au-dessus mais au service de la Parole de Dieu. En particulier, le magistère, de par mandat, exprès reçu du Christ, et avec l'assistance de l'Esprit Saint, écoute avec pièté, garde saintement et expose fidèlement le dépôt révélé. A cet égard, le rôle joué par les théologiens, fondé avant tout sur les recherches scientifiques, n'est qu'auxiliaire.

Parlant généralement, on désigne par le magistère de l'Eglise la fonction d'annoncer parpétuellement la Parole de Dieu en son nom et avec son autorité et d'en définir le sens, s'il le faut. Le successeur de Pierre. pontife romain, constitue sa vive personification. En principe, le magistère pontifical se divise en solennel ou bien infaillible et en ordinaire, c'est-à-dire authentique. A présent, l'un et l'autre font l'objet d'un enseignement conciliaire.

L'infaillibilité papale a été définie par le Vatican I dans la I-ère Constitution dogmatique sur l'Eglise Pastor aeternus. La Constitution dogmatique sur l'Eglise de Vatican II, Lumen gentium, la répète seulement avec quelques développements. Selon ces documents conciliaires le pape parlant ex cathedra, possède la même infaillibilité que l'Eglise. Cela signifie qu'il doit exercer sa charge de pasteur et de docteur de tous les chrétiens et définir, en vertu de la suprême autorité apostolique, la doctrine de foi et de morale à tenir par l'Eglise universelle. En raison de l'ássistance divine, lui promise en personne de Pierre, les décisions doctrinales de ce genre sont par elles-mêmes, et non par un accord que leur donnerait postérieurement l'Eglise, irréformables. Gardant toujours essentiellement le même contenu révélé, elles peuvent néanmoins être perfectionnées sous divers aspects, 
spécialement dans le domaine du langage. Les fidèles doivent les suivre avec l'obéissance due à la foi divine et catholique.

Les définitions dogmatiques, portées par le seul souverain pontife pour raison grave, sont très rares. Normalement les papes se servent du magistère authentique qui, n'excluant pas l'approfondissement ultérieur de la question, jouit d'une grande autorité. Il y en a différentes formes d'expression. C'est le Credo qui constitue la plus ancienne. A présent, les évêques de Rome prononcent le plus souvent des discours adressés aux visiteurs-pèlerins ou ils publient les encycliques pour rappeier la foi de l'Eglise à propos d'un problème d'actualité. La certitude théologique, possédée en ce cas par leurs affirmations, est assez variée. Bien qu'il y ait parmi elles les thèses infaillibles, cet enseignement ordinaire peut contenir aussi des erreurs à corriger. Avant les autres choses, tout dépend de deux facteurs, à savoir de la relation existant entre lui-même et la Révélation, ainsi que de l'engagement de l'autorité pontificale. C'est pourquoi en appéciant la valeur théologique du magistère authentique il faut passer par-dessus les préjugés et essayer de préciser sa juste qualification. Les directives à ce sujet sont données, d'une manière singulière, par la Lumen gentium. En général, il oblige les fidèles, bien sûr conscients de différents genres de la certitude théologique, à l'assentiment intérieur ainsi qu'extérieur.

C'est le conditionnement historique de la Révélation qui fait exister le magistère de l'Eglise, par la volonté divine. Le dépôt révélé, adapté toujuors aux nouvelles conditions de la vie humaine doit rester le même, sans un changement essentiel du contenu doctrinal. Or, le magistère pontifical contribue, d'une manière considérable, à son identité profonde dans l'accroissement continuel. 